\title{
Excessive carbohydrate intake in pregnancy and neonatal obesity: study in Cap Bon, Tunisia
}

\author{
I DE SCHAMPHELEIRE, M A PARENT, AND C CHATTEUR
}

Projet Tuniso-Belge de Médecine Intégrée au Cap Bon, Nabeul, Tunisia

SUMMARY A high incidence (over $20 \%$ ) of obesity was found in 250 neonates living in a rural area of Tunisia, by using weight and ponderal index per gestational age as the nutritional index. Maternal diabetes was probably excluded. Two surveys on nutritional habits-one on the general population and the other on pregnant women-showed a tendency to consume a high carbohydrate and low protein diet. The effect of a badly balanced maternal diet on the fetus is discussed.

The Cap Bon peninsula is a fertile region of Tunisia, with a sedentary population living mainly on agriculture, fishing, craftsmanship, and tourism. The fact that there are so many 'big babies' at birth prompted us to try to define fetal growth and nutrition. If more were known about the nutritional features of this population of neonates, there could be a better understanding of the country's health problems. A strategy of nutritional education for the pregnant woman and her child could then be established.

\section{Materials and methods}

We studied 250 newborn babies chosen at random from a nursery in Beni Khalled, a small town with a population of 10000 in Cap Bon. The babies were all singletons, so 4 pairs of twins were excluded. The nursery is under the control of a midwife who is herself supervised by a doctor. Any dystocia requiring medical intervention is referred to the nearby regional hospital.

Gestational age was determined using Dubowitz's method, ${ }^{1}$ as we found in a blind study that this gave a margin of error of \pm 1 week. ${ }^{2}$ Nutritional status was assessed using the method of Lubchenco et al. ${ }^{3-4}$ Rohrer's ponderal index (PI) was used to calculate the relative amount of soft tissue mass present in an infant. ${ }^{5-6}$ This was calculated as follows: birthweight (in $\mathrm{g}$ )/crown-to-heel length (in $\mathrm{cm}^{3}$ ) $\times 100$. Using PI curves related to gestational ages the following classification was made (see Fig. 2). (1) Above the 97th centile: markedly excessive accumulation of soft tissue mass (marked obesity).

(2) Between the 90th and the 97th centiles: moderately excessive accumulation of soft tissue mass (moderate obesity).
(3) Between the 10th and the 90th centiles: proportionate soft tissue mass.

(4) Between the 3rd and the 10th centiles: moderately reduced soft tissue mass (moderate malnutrition).

(5) Below the 3rd centile: markedly reduced soft tissue mass (severe malnutrition).

Because PI curves vary between one recommended method and another we chose Miller's classification, ${ }^{5-7}$ as the mean birthweight per gestational age of his neonates was close to that of ours.

The diet of 150 pregnant women was assessed individually, by interviewing each woman. Student's $t$ test was used for statistical analysis.

Urine samples of 600 women were screened for sugar using Benedict's reagent.

\section{Results}

The mean birthweights per gestational ages are shown in Table 1. Classification according to weight and gestational age is shown in Fig. 1 and Table 2.

$77 \%$ of neonates had normal birthweights, ${ }^{5} 0.8 \%$ were small-for-dates, and a rather high percentage (22\%) were large-for-dates. $5.6 \%$ of all neonates had birthweights $<2500 \mathrm{~g}$ excluding twins $(7 \cdot 7 \%$ including them). The frequency of prematurity was $20.8 \%$.

The mean PI per gestational age is shown in Table 3.

No statistically significant differences were found between the means of any group at any week of gestation using Student's $t$ test, except for girls at term. This lack of variation from week to week is in keeping with Miller's observations. Thus the need to determine gestational age precisely is not an 
Table 1 Mean birthweights per gestational ages of 250 neonates

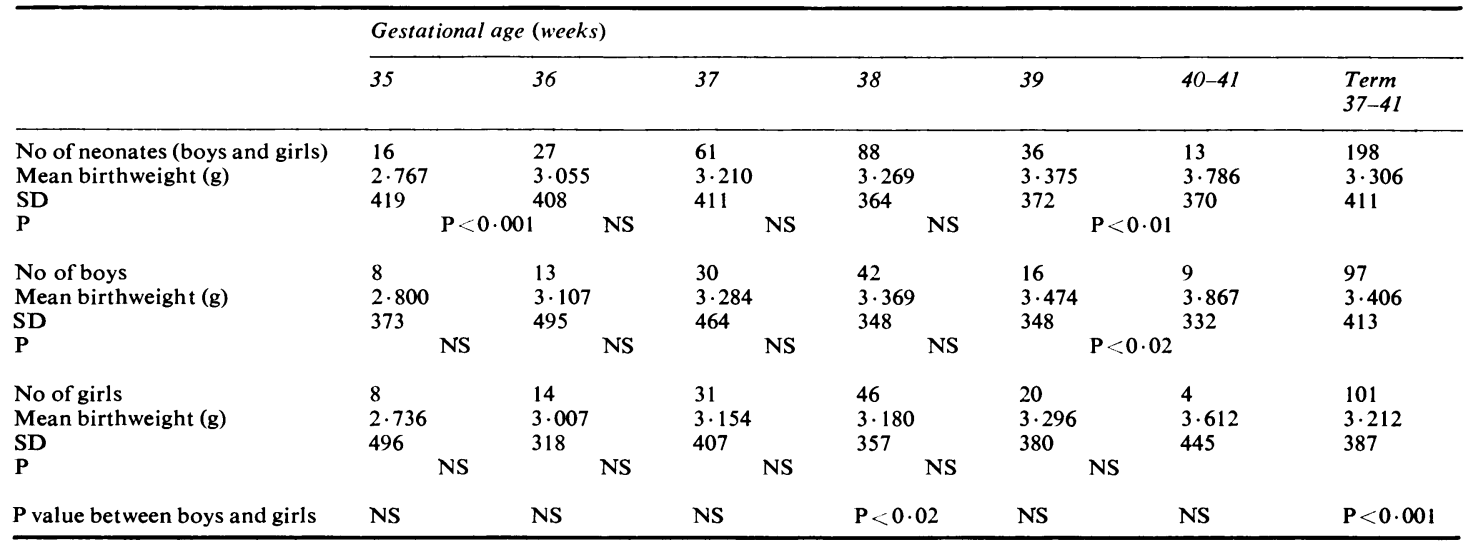

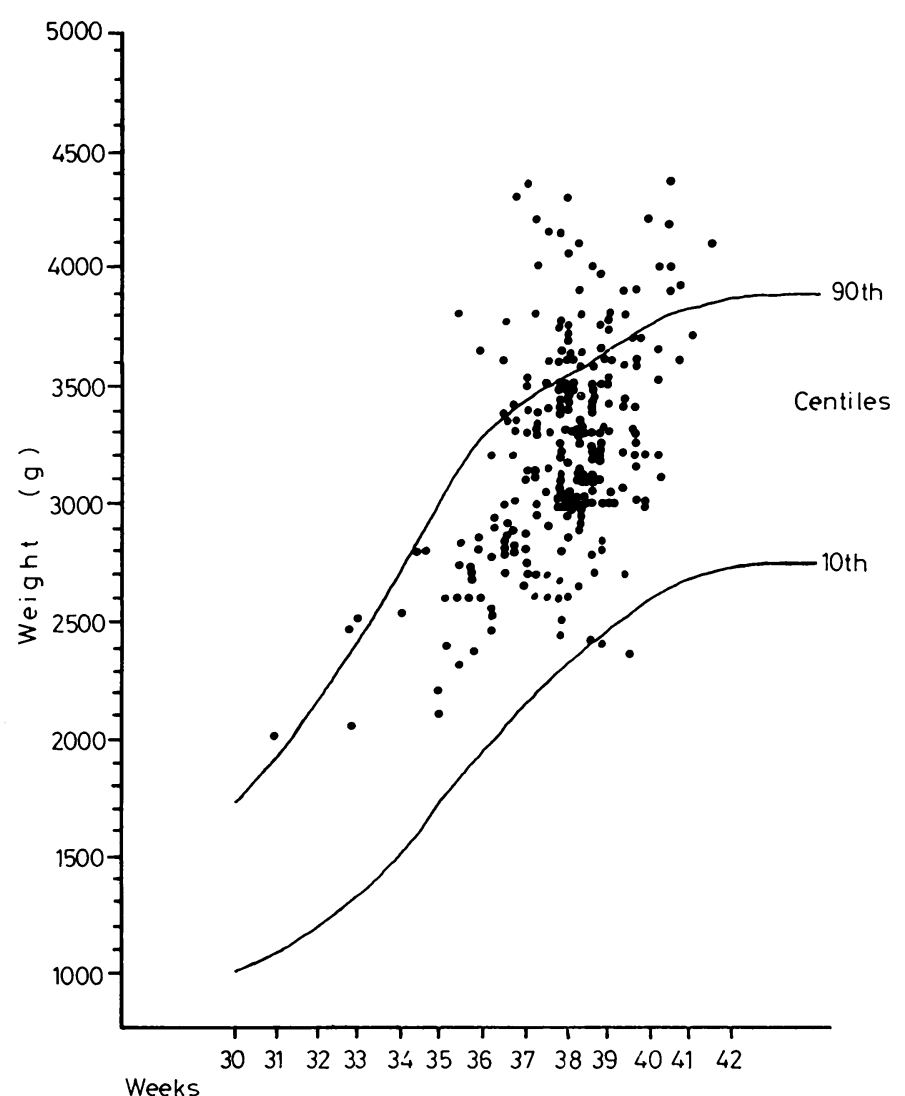

Fig. 1 Classification of neonates according to weight and gestational age. 
essential requirement for nutritional classification for babies thought to be term ones. ${ }^{6-7}$ Fig. 2 and Table 4 show the classification according to PI and gestational age.

$23.2 \%$ of neonates had excessive amounts of soft tissue mass, of whom $10.8 \%$ had a pronounced excess and $12 \cdot 4 \%$ a moderate excess. $7 \cdot 2 \%$ had reduced amounts of soft tissue mass (moderate $6.4 \%$ and severe $0.8 \%$ ).

If two methods of assessing nutrition are compared (birthweight and PI per gestational age) the following results can be found: (1) in the group of large babies ( $>90$ th centile), $73 \%$ had a high PI and $27 \%$ a normal PI; (2) all small-for-dates babies had a normal PI; (3) in the group of neonates with a high PI (90th centile), 69\% were large-for-dates, and $31 \%$ were of appropriate weights for ages; (4) all neonates with a low PI had weights appropriate for ages.

Each method seemed to measure different characteristics of growth. Among the large babies, $73 \%$ had excessive amounts of soft tissue mass and

Table 2 Classification of 250 neonates according to weight and gestational age

\begin{tabular}{|c|c|c|c|c|c|c|c|c|c|c|}
\hline \multirow{4}{*}{$\begin{array}{l}\text { Weight } \\
\text { (centiles) }\end{array}$} & \multicolumn{8}{|c|}{ Gestational age (weeks) } & & \\
\hline & \multicolumn{3}{|c|}{ Preterm $(20.8 \%)$} & \multicolumn{5}{|c|}{$\operatorname{Term}(79.2 \%)$} & \multirow{2}{*}{\multicolumn{2}{|c|}{ Total }} \\
\hline & $30-34$ & 35 & 36 & 37 & 38 & 39 & 40 & 41 & & \\
\hline & $\begin{array}{l}n=9 \\
(3 \cdot 6 \%)\end{array}$ & $\begin{array}{l}n=16 \\
(6.4 \%)\end{array}$ & $\begin{array}{l}n=27 \\
(10.8 \%)\end{array}$ & $\begin{array}{l}n=61 \\
(24.4 \%)\end{array}$ & $\begin{array}{l}n=88 \\
(35.2 \%)\end{array}$ & $\begin{array}{l}\overline{n=36} \\
(14.4 \%)\end{array}$ & $\begin{array}{l}n=11 \\
(4 \cdot 4 \%)\end{array}$ & $\begin{array}{l}n=2 \\
(0.8 \%)\end{array}$ & No & $\%$ \\
\hline $\begin{array}{l}\text { Large } \\
\text { (>90th) } \\
\text { Appropriate }\end{array}$ & 3 & 2 & 5 & 14 & 17 & 7 & 6 & 1 & 55 & 22 \\
\hline $\begin{array}{l}\text { (10-90th) } \\
\text { Small }\end{array}$ & 6 & 14 & 22 & 47 & 70 & 28 & 5 & 1 & 193 & $77 \cdot 2$ \\
\hline$(<10$ th $)$ & 0 & 0 & 0 & 0 & 1 & 1 & 0 & 0 & 2 & 0.8 \\
\hline
\end{tabular}

Table 3 Mean ponderal index per gestational age

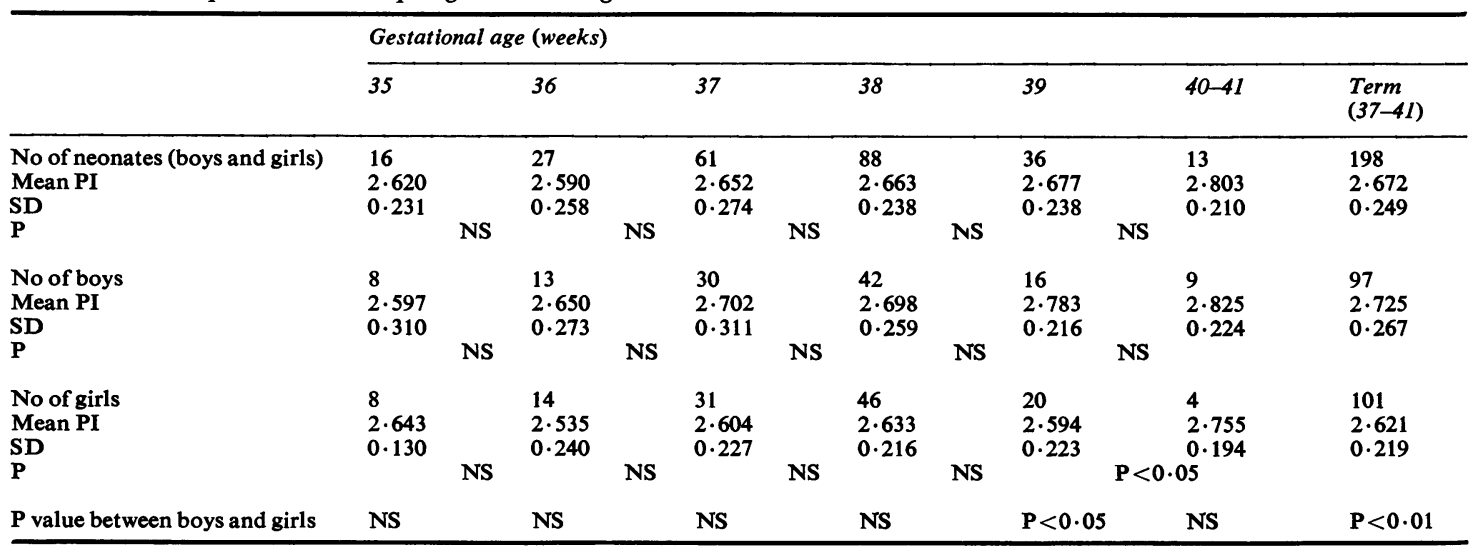

Table 4 Classification of 250 neonates according to ponderal index and gestational age

\begin{tabular}{|c|c|c|c|c|c|c|c|c|c|c|}
\hline \multirow{3}{*}{$\begin{array}{l}\text { Ponderal index } \\
\text { (centile) }\end{array}$} & \multicolumn{8}{|c|}{ Gestational age (weeks) } & \multirow{2}{*}{\multicolumn{2}{|c|}{ Total }} \\
\hline & \multirow{2}{*}{$\begin{array}{l}30-34 \\
(n=9)\end{array}$} & \multirow{2}{*}{$\begin{array}{l}35 \\
(n=16)\end{array}$} & \multirow{2}{*}{$\begin{array}{l}36 \\
(n=27)\end{array}$} & \multirow{2}{*}{$\begin{array}{l}37 \\
(n=61)\end{array}$} & \multirow{2}{*}{$\begin{array}{l}38 \\
(n=88)\end{array}$} & \multirow{2}{*}{$\begin{array}{l}39 \\
(n=36)\end{array}$} & \multirow{2}{*}{$\begin{array}{l}40 \\
(n=11)\end{array}$} & \multirow{2}{*}{$\begin{array}{l}41 \\
(n=2)\end{array}$} & & \\
\hline & & & & & & & & & No & $\%$ \\
\hline$>97$ th & 1 & 3 & 3 & 7 & 6 & 4 & 2 & 1 & 27 & $10 \cdot 8$ \\
\hline $90-97$ th & 0 & 0 & 2 & 7 & 14 & 5 & 3 & $\mathbf{0}$ & 31 & $12 \cdot 4$ \\
\hline 10-90th & 5 & 13 & 20 & 42 & 63 & 24 & 6 & 1 & 174 & 69.6 \\
\hline 3rd-10th & 2 & 0 & 2 & 5 & 4 & 3 & $\mathbf{0}$ & 0 & 16 & $6 \cdot 4$ \\
\hline$<3$ rd & $\overline{1}$ & $\mathbf{0}$ & 0 & 0 & 1 & 0 & $\mathbf{0}$ & 0 & 2 & 0.8 \\
\hline
\end{tabular}




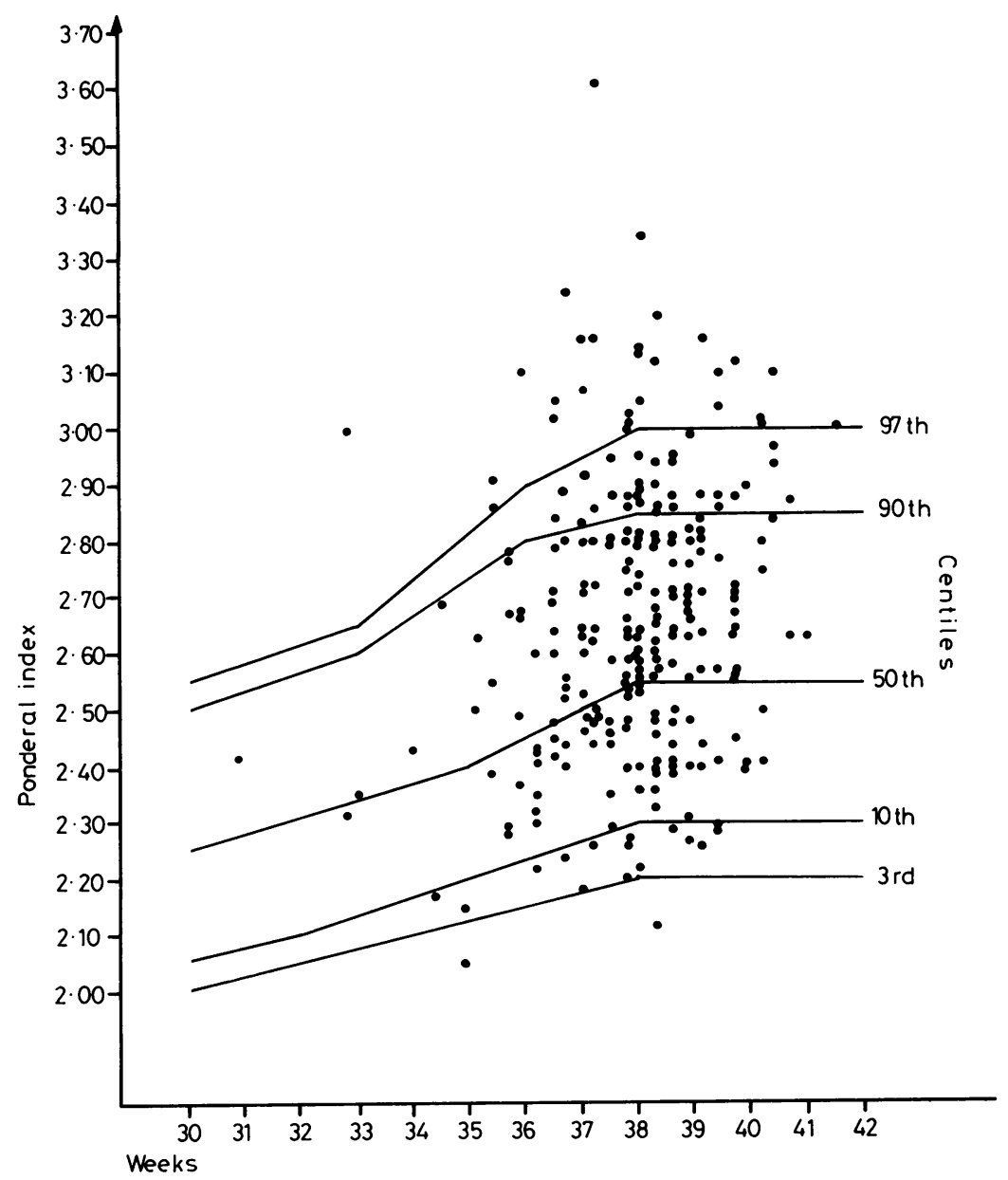

Fig. 2 Classification of neonates according to ponderal index and gestational age.

could truly be described as obese, while $27 \%$ had a proportionately normal soft tissue mass and could thus be described as tall. A greater number of obese infants could be diagnosed by using the PI centiles (31\% more) than by using birthweights only. PI centiles also gave a more accurate diagnosis of intrauterine growth retardation. Indeed, 18 neonates had a low PI and normal birthweights.

A study of dietary habits of 150 pregnant women ${ }^{26}$ had shown that the daily diet was based monotonously on couscous, pasta and bread, vegetables and fruit in season. Olive oil was profusely used for cooking and was even drunk; only one-third of these women could afford to eat meat more than twice a week; fish was sometimes part of the menu if in season and available; one-third of them did not eat eggs, and half of them did not drink milk or eat milk products.
There was only one positive result in the urine samples of 600 pregnant women who were screened for sugar. Further investigations for diabetes were not considered necessary.

\section{Discussion}

The mean birthweight of term neonates in our series, and in several other series in Tunisia, ${ }^{8-9}$ was similar to that found in industrialised countries. Birthweight alone was not a reliable indicator of fetal growth impairment, ${ }^{6-7}$ and a more accurate assessment of the nutritional status could be made by using weight and the PI per gestational age.

We found a large proportion of big babies in our population. More than $20 \%$ of them were heavy at birth and had excessive soft tissue mass, $73 \%$ of them were truly obese, and $27 \%$ were tall babies. 
Data from developing countries suggest that the prevalence of obesity is increasing. Although it is usually fairly low in the general population, it can be surprisingly high among segments of the population. ${ }^{10-11}$

Theories about obesity vary but many reports suggest there is a possible correlation between weight in infancy, weight in childhood, and weight in adulthood. ${ }^{11-19}$

None of the 250 mothers was a known diabetic and the urine results from 600 pregnant women in the same population make diabetes an unlikely explanation for neonatal obesity.

The nutritional habits of the general population in Tunisia suggest possible explanations for the high frequency of neonatal obesity. The total intake of kcal per caput a day in Tunisia is $2250 .^{20}$ This figure is close to the general mean figure found in developing countries $(2200 \mathrm{kcal}$ per caput a day). The normal diet is generally badly balanced. Indeed, a recent national study on nutrition showed the following proportions of caloric intakes in the local diet: ${ }^{21}$ carbohydrates $62.0 \%$, proteins $11.6 \%$, and lipids $26.4 \%$. This is a rather high carbohydrate and low protein diet. The main sources of calories are provided from cereals $(62.2 \%)$ and olive oil $(18 \cdot 2 \%)$. Only $14 \%$ of proteins are of animal origin, while $86 \%$ are of vegetable origin (of which $75 \%$ are cereals). Olive oil is the main source of lipids $(69 \cdot 5 \%)$, the rest coming from cereals and animal products. No difference was found in dietary habits between pregnant women and the general population.

The importance of the nutritional status of a pregnant woman and the effect of her diet on her baby during pregnancy are well documented. ${ }^{17}$ 22-24 A badly balanced and mainly hyperglucidic diet in the mother during the time of her pregnancy would lead to continuous proportionately higher passage of glucose and to a badly balanced 'fetal diet'.

The clinical importance of fetal carbohydrate metabolism was reviewed by Gabbe and Quilligan. ${ }^{25}$ Placental transfer of glucose is characterised as facilitated diffusion. Thus, although diabetic glucose levels are not reached in the mother, higher levels than normal are obtained in the fetus over a long period of time. The duration rather than the degree of hyperglycaemia may be important. As maternal insulin does not cross the placenta, the fetus responds to the continuous increased glucose supply by increasing his own insulin secretion. This increase in substrate and insulin results in more glycogen synthesis, more adipose tissue, and a macrosomic infant. This series of mechanisms may explain the nature of obesity found in the babies in our population.
The high frequency with which neonatal obesity was found, and the knowledge of the dietary habits of pregnant women should lead to a specific strategy of nutritional education. Such a strategy should aim at improving the balance of nutritional intakes-that is, decreasing carbohydrates and increasing proteins (meat, fish, eggs). If for lack of money and reasons of custom the diet has to be mainly of vegetable origin, an appropriate combination of vegetables would provide all the essential amino-acids (chick peas, beans).

\section{References}

1 Dubowitz L M S, Dubowitz V, Goldberg B A. Clinical assessment of gestational age in the newborn infant. J Pediatr 1970; 77: 1-10.

2 De Schampheleire I, Parent M A, Chatteur C. Evaluation de l'application d'une méthode de détermination de l'état nutritionnel d'une population de nouveau-nés à la maternité. Résultats préliminaires. In: Rapport Annuel 1977. Tunisia: Projet Tuniso-Belge de Médecine Intégrée au Cap Bon, 1977: 50-65.

3 Lubchenco L O, Hansman C, Dressler M, Boyd E. Intrauterine growth as estimated from liveborn birthweight data at 24 to 42 weeks of gestation. Pediatrics 1963; 32: 793-800.

4 Battaglia F C, Lubchenco L O. A practical classification of newborn infants by weight and gestational age. $J$ Pediatr 1967; 71 : 159-63.

5 Lubchenco L O, Hansman C, Boyd E. Intrauterine growth in length and head circumference as estimated from live births at gestational ages from 26 to 42 weeks. Pediatrics 1966; 37: 403-8.

- Miller H C, Hassanein K. Diagnosis of impaired fetal growth in newborn infants. Pediatrics 1971 ; 48: 511-22.

7 Miller H C, Hassanein K. Fetal malnutrition in white full-term newborn infants: maternal factors. Pediatrics 1973; 52: 504-12.

8 Beghin D, Jerfal I. Le poids des nouveau-nés de la ville de Grombalia, Cap Bon. Arch Inst Pasteur Tunis 1973; 50: $239-42$.

- Hamza B, Caruana M, Casanova C. Dénutrition grave du nourrisson. Maroc Médical 1956; 372: 35-56.

10 Beaton G H. Nutritional problems of affluence. In: Beaton $\mathbf{G} \mathbf{H}$, Bengoa $\mathrm{J} \mathbf{M}$, eds. Nutrition in preventive medicine. World Health Organisation Monograph Series No. 62. Geneva: WHO, 1976: 482-97.

11 Jelliffe D B, Jelliffe P E. Fat babies: prevalence, perils, and prevention. J Trop Pediatr 1975; 21 : 124-59.

12 Charney E, Goodman H, McBride M, Lyon B, Pratt R. Childhood antecedents of adult obesity. Do chubby infants become obese adults? N Engl J Med 1976; 295: 6-9.

13 Häger A. Adipose cell size and number in relation to obesity. Postgrad Med J 1977; 53: Supplement 2, 101-10.

14 Hirsch J. The adipose cell hypothesis. N Engl J Med 1976; 295: 389-90.

15 Lloyd J K. Prognosis of obesity in infancy and childhood. Postgrad Med J 1977; 53: 111-20.

16 Ravelli G-P, Stein Z A, Susser M W. Obesity in young men after famine exposure in utero and early infancy. N Engl J Med 1976; 295: 349-53.

17 Whitelaw A G L. Influence of maternal obesity on subcutaneous fat in the newborn. $\mathrm{Br}$ Med J 1976; i: 985-6. 
18 Whitelaw A G L. Infant feeding and subcutaneous fat at birth and at one year. Lancet 1977; ii: 1098-9.

19 Weil W B. Current controversies in childhood obesity. J Pediatr 1977; 91: 175-87.

${ }^{20}$ Food and Agriculture Organisation. Food production. In: Beaton $\mathbf{G ~} \mathrm{H}$, Bengoa $\mathrm{J} \mathbf{M}$, eds. Nutrition in preventive medicine. World Health Organisation Monograph Series No. 62. Geneva: WHO, 1976: 335.

21 Institut National de Nutrition et de Technologie Alimentaire. Nutrition en Tunisie; planification et programmation. In: Premier Rapport Annuel 1978. Tunisia: Ministry of Public Health, 1978: 57.

${ }^{22}$ Edwards L E, Dickes W, Alton I, Hakanson E. Pregnancy in the massively obese: course, outcome, and obesity prognosis of the infant. Am J Obstet Gynecol $1978 ; 131$ : 479-83.

${ }^{23}$ Lechtig A, Martorell R, Delgado H, Yarbrough C,
Klein R. Food supplementation during pregnancy, maternal anthropometry, and birth weight in a Guatemalan rural population. J Trop Pediatr 1978; 24: 217-22.

24 Naeye $R$ L, Blane W, Paul C. Effects of maternal nutrition on the human fetus. Pediatrics $1973 ; 52: 494-503$.

${ }^{25}$ Gabbe S G, Quilligan E J. Fetal carbohydrate metabolism: its clinical importance. Am J Obstet Gynecol 1977; 127: 92-103.

${ }^{26}$ Ben Kahla R. Habitudes alimentaires des femmes enceintes au Cap Bon, Tunisie. In: Rapport Annuel 1979. Tunisia: Projet Tuniso-Belge de Médicine Intégrée au Cap Bon. In press.

Correspondence to Dr M A Parent, Projet TunisoBelge de Médecine Intégrée au Cap Bon, BP 10, Nabeul, Tunisia.

Received 3 July 1979 